\title{
PENDAMPINGAN PEMBUATAN MODUL, SOAL, DAN TUGAS BERBASIS DARING UNTUK GURU SMP NEGERI 30 SEMARANG
}

Online Guidance of Module, Quiz, and Assessment Creating for Teachers of SMP Negeri 30 Semarang

\author{
Septian Enggar Sukmana ${ }^{1}$, Defri Kurniawan ${ }^{2}$, Prajanto Wahyu Adi ${ }^{3}$ \\ 1,2,3 Teknik Informatika Universitas Dian Nuswantoro, Jalan Imam Bonjol 207, (+6224) \\ 3517261 \\ e-mail: 1septian.enggar@dsn.dinus.ac.id, 2defri.kurniawan@dsn.dinus.ac.id, \\ 3prajanto@dsn.dinus.ac.id
}

\begin{abstract}
Abstrak
Penerapan e-Learning di berbagai sekolah perlu dilaksanakan maka diperlukan desiminasi terhadap pemahaman e-Learning di berbagai sekolah. Pemahaman mengenai eLearningdi sekolah akan mengarah kepada implementasi e-Learning di sekolah tersebut. Tanpa desiminasi pemahaman dan pendampingan kepada guru-guru sekolah terhadap penggunaan eLearning, maka sulit untuk terwujud suatu pembelajaran yang interaktif, kreatif dan mampu meningkatkan prestasi serta motivasi belajar siswa di sekolah. Pengembangan e-learning telah dilakukan oleh mitra pengabdian masyarakat yaitu SMPN 30 Semarang. Permasalahan muncul ketika implementasi e-learning di sekolah tersebut untuk kegiatan belajar-mengajar yaitu kurang optimalnya penggunaan media e-learning tersebut. Oleh karena itu, inisiatif pemberian pendampingan oleh beberapa dosen Universitas Dian Nuswantoro kepada para guru dapat menjadi solusi atas masalah tersebut. Kegiatan pendampingan yang dilakukan meliputi pembuatan modul, kuis, dan tugas. Hasil yang diperoleh menunjukkan para guru mampu mengoperasikan sistem manajemen pembelajaran dan diharapkan pendampingan secara intensif lebih sering dilakukan.
\end{abstract}

Kata kunci - pembelajaran elektronik, pembelajaran berbasis daring, sistem manajemen pembelajaran, pendampingan guru

\begin{abstract}
E-learning implementation must be held by each school in Indonesia, so it requires dessimination of e-learning understanding to that school. This understanding would be pointed to the school based on that school conditions that happen in that school. Without dissemination, this understanding would be meaningless and inetractivity of learning won't be implemented optimally. E-learning system has been developed in SMPN 30 Semarang, but it is not implemented well, so a team from Universitas Dian Nuswantoro which consists of some lectures of this campus has inisiative to help to tackle this problem. Guidance will be the best step to tackle this problem by guiding all teachers to develop module, quiz, and assessment based online using e-learning system that has been developed in this school. The result shows that teachers can follow the instructions of making module, quiz, and assessment well. Hopefully, this guidance activity can be performed more intensively.
\end{abstract}

Keywords-e-learning, learning based online, learning management system, teacher guidance 


\section{PENDAHULUAN}

Berdasarkan Undang-undang No 14 Tahun 2015 tentang Guru dan Dosen. Guru merupakan pendidik profesional yang memiliki tugas utama mendidik, mengajar, membimbing, mengarahkan, melatih, menilai, dan mengevaluasi peserta didik [1]. Peran tersebut menjadikan guru sebagai suatu profesi yang dituntut untuk terus berkembang pada sisi pengetahuan materi, cara mendidik dan kemampuan mengajarnya. Guru menjadisuatu ujung tombak dalam pembelajaran siswa di kelas. Pada proses Kegiatan Belajar Mengajar (KBM), seorang guru menggunakan alat bantu atau media dalam memberikan pemahaman pelajaran pada para siswanya baik melalui whiteboard, LCD projector, menggunakan bangun ruang, peta, bola dunia maupun alat bantu lainnya.

Perkembangan internet yang cepat menjadikan internet telah diaplikasikan dalam memudahkan pekerjaan pada setiap sektor atau bidang kehidupan, baik pada pelayanan transportasi, perbankan, kesehatan (rumah sakit) dan digunakan pada bidang pendidikan sebagai media pembelajaran. Hasil riset Kominfo dan UNICEF tahun 2014 mengenai perilaku anak dan remaja dalam menggunakan internet, ditemukan bahwa $98 \%$ remaja tahu internet dan 79,5\% adalah pengguna internet [2].Berdasarkan hasil riset tersebut apabila penggunaan internet dioptimalkan melalui sekolah dalam bentuk pemberian materi, tugas, forum diskusi ataupun latihan soal secara online maka dapat memberikan manfaat positif bagi penggunaan internet di kalangan remaja dan membantu mereka dalam meningkatkan pemahaman serta motivasi dalam belajar.

Media pembelajaran berbasis internet atau diistilahkan dengan e-learning[3], merupakan media pembelajaran yang memadukan penggunaan teknologi internet. Media merupakan bentuk jamak dari "medium" yang berarti pengantar. Sedangkan pembelajaran menggambarkan usaha guru dalam membuat siswa belajar [4]. Dengan menggunakan internet sebagai basis pembelajarannya, maka para siswa dalam belajar tidak terbatas oleh ruang dan waktu karena semua materi, grup diskusi, latihan soal berada pada suatu wadah / media di internet yang dapat diakses yang dapat diakses 24 jam dan dimanapun siswa berada. Pencarian informasi pun lebih cepat dibandingkan ketika mencari informasi pada halaman-halaman buku. Jika dibandingkan dengan membeli buku atau majalah tentu penggunaan internet yang berbasiskan kuota paket data lebih murah.

Banyak manfaat yang bisa didapatkan dari penggunaan internet sebagai media pembelajaran di sekolah tidak sesuai dengan pemerataan penggunaan aplikasi di berbagai sekolah. Kendala pengembangan e-Learningdi sekolah diantaranya bisa dilihat dari faktor budaya, kebijakan dan regulasi serta infrastruktur [4]. Faktor budaya merupakan faktor yang cukup sulit diselesaikan ketika pemikiran masyarakat setempat atau para guru maupun pengelola sekolah masih menjadikan pembelajaran konvensional sebagai pembelajaran yang tak tergantikan. Pembelajaran harus dengan bentuk tatap muka dimana guru akan condong dominan sebagai pemberi ilmu dan siswa sebagai pemberi ilmu. Padahal pada e-Learning siswa akan menjadi pihak yang dominan dan guru hanya sebagai fasilitator. Faktor kedua adalah faktor kebijakan dan regulasi, sekolah harus mengambil keputusan atau bersikap dengan adanya kecanggihan teknologi informasi. Sekolah mendukung untuk ambil bagian dalam pemanfaatan media pembelajaran berbasis internet ini atau hanya tetap menggunakan pembelajaran konvensional saja. Faktor yang ketiga adalah faktor infrastruktur, faktor ini cukup memberi andil dalam kesuksesan pengembangan e-Learning. Persiapan infrastruktur seperti jaringan internet atau intranet, komputer, server ataupun software e-Learning harus disesuaikan dengan besarannya anggaran. Semakin besar anggaran yang dialokasikan untuk pengembangan eLearning ini maka akan semakin baik tingkat kehandalan e-Learning tersebut.

Berdasarkan paparan yang telah disampaikan, penerapan e-Learning di berbagai sekolah perlu dilaksanakan maka diperlukan desiminasi terhadap pemahaman e-Learning di berbagai 
sekolah. Pemahaman mengenai e-Learningdi sekolah akan mengarah kepada implementasi eLearning di sekolah tersebut. Tanpa desiminasi pemahaman dan pendampingan kepada guruguru sekolah terhadap penggunaan e-Learning, maka sulit untuk terwujud suatu pembelajaran yang interaktif, kreatif dan mampu meningkatkan prestasi serta motivasi belajar siswa di sekolah. Adapun sekolah yang menjadi objek IPTEKS Bagi Masyarakat (IBM) dalam rangka pengabdian masyarakat ini adalah SMP Negeri 30 Semarang yang beralamat di Jl. Amarta No. 21, Semarang. Berdasarkan lokasi SMPN 30 Semarang terletak di kota Semarang sehingga jaringan internet memiliki sinyal yang kuat untuk implementasi penggunaan e-Learning. Pengabdian ini diharapkan dapat memberikan pemahaman dan pendampingan penggunaan eLearning pada guru-guru SMPN 30 Semarang sehingga dapat menciptakan pembelajaran yang lebih interaktif dan mampu meningkatkan motivasi dan pemahaman siswa.

\section{METODE PENELITIAN}

Pelaksanaan pendampingan dilaksanakan di SMPN 30 Semarang dengan diikuti oleh para guru pengampu mata pelajaran di sekolah tersebut. Lokasi ruang yang dipakai pada kegiatan pendampingan ini adalah ruang guru SMP Negeri 30 Semarang, penggunaan ruang ini lokasi pendampingan ditujukan sebagai bentuk kenyamanan mobilitas lingkungan oleh guruguru SMP Negeri 30 Semarang. Kegiatan pendampingan ini dilakukan melalui tahapan tahapan pendampingan antara lain: 1) Koordinasi dengan pihak SMP Negeri 30 Semarang yang terdiri dari Kepala sekolah dan wakil kepala bidang kurikulum untuk menentukan jumlah guru dan teknis pelaksanaan pelatihan; 2) Penentuan waktu dan tempat pelaksanaan serta petunjuk teknis yang perlu dilakukan; 3) Penyusunan materi pelatihan; 4) Pengembangan sistem aplikasi live chat untuk pembelajaran; 5) Penyebaran undangan pelatihan ke guru-guru SMP Negeri 30 Semarang; 6) Persiapan teknis pelaksanaan bersifat fisik antara lain: kesiapan computer dan perangkat mobile, perangkat dokumentasi, backdrop, konsumsi, materi hard-print, dan daftar hadir; 7) Persiapan teknis pelaksanaan secara non-fisik antara lain: website untuk ujian online, server ujian online, materi presentasi pelatihan soft-copy, dan ketersediaan internet. 8) Pembentukan tim untuk konsultasi yang berfungsi menangani permasalahan-permasalah yang dimungkinkan muncul pada saat kegiatan pelatihan dilaksanakan; 9) Pengumpulan dokumentasi yang bersifat administratif sebagai penyusunan laporan pertanggungjawaban.

Pelaksanaan pendampingan dilakukan melalui tiga kegiatan, yaitu pembuatan modul, kuis, dan tugas. Setiap langkah melibatkan satu instruktur utama dan dua instruktur pendamping dengan pembagian pergantian tim pengabdian untuk menjadi isntruktur utama dan pendamping. Gambar 1 menunjukkan tahapan kegiatan pendampingan yang dilakukan. 


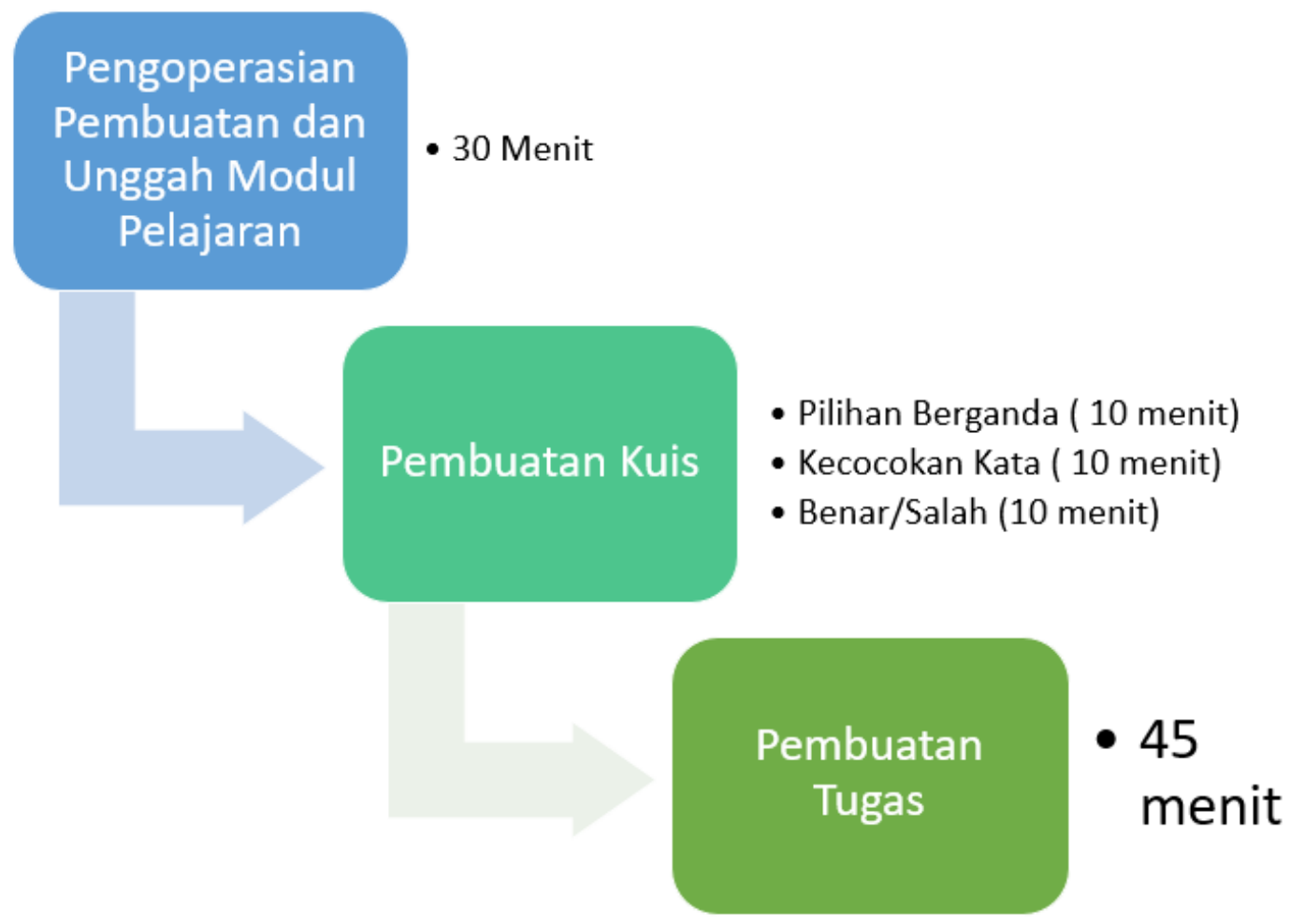

Gambar 1 Pendampingan langsung kepada guru saat kegiatan pembuatan soal berbasis online Pada setiap tahapan kegiatan pendampingan, pengamatan terhadap ketercapaian guru di setiap langkah juga dilakukan untuk mengetahui keberhasilan dari kegiatan pendampingan yang dilakukan.

\section{HASIL DAN PEMBAHASAN}

Pembuatan soal-soal menggunakan CMS Moodle telah dikembangkan di sebuah server yang dapat diakses di www.smpn30-semarang.info. Pendampingan ini terbagi menjadi dua tahap utama yaitu penjelasan cara akses dan penjelasan cara pembuatan quiz. Penjelasan cara akses diperlukan karena sistem yang siap dipakai secara online ini perlu diperkenalkan kepada para guru agar dapat diakses untuk keperluan pembelajaran di kelas, sedangkan penjelasan cara pembuatan soal diperkenalkan kepada guru supaya guru dapat mengoptimalkan pembelajaran dan evluasi melalui sistem dan soal berbasis online yang telah dibuat. Selain penjelasan teknis yang dilakukan dengan sistem ceramah dari pemateri ke guru-guru SMP Negeri 30 Semarang, pada saat yang bersamaan para guru juga didampingi oleh para fasilitator yang merupakan tim pengabdian masyarakat sehingga guru dapat langsung mempraktikkan penggunaan dari sistem online tersebut. 


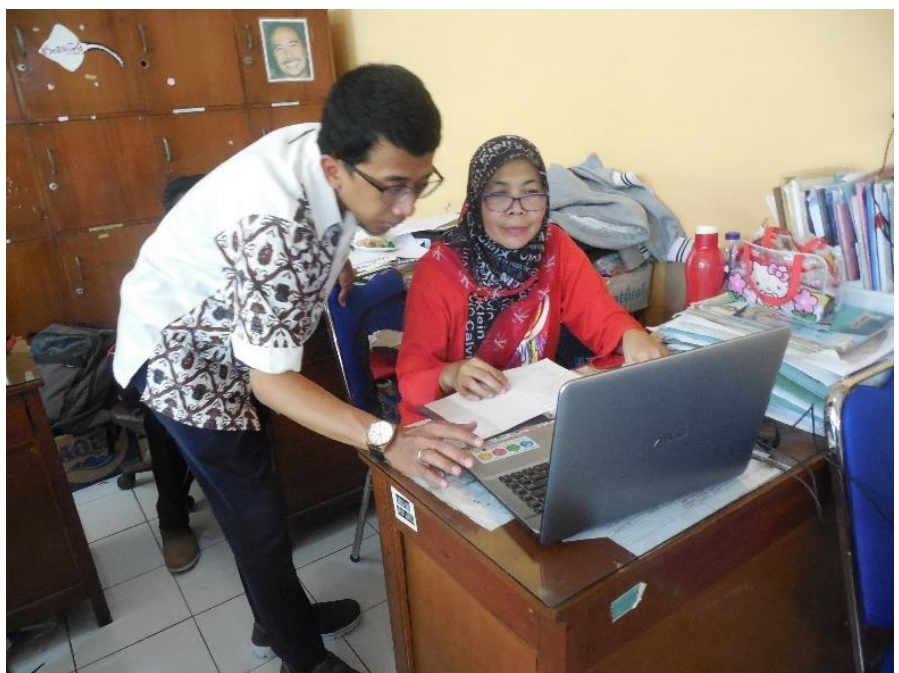

Gambar 2 Pendampingan langsung kepada guru saat kegiatan pembuatan soal berbasis online

Pemaparan cara akses dimulai dari penyampaian alamat akses tersebut. Alamat sistem sengaja dibuat di luar server sekolah karena pada saat ini server sekolah belum memungkinkan untuk ditambahkan sistem pembelajaran online tersebut. Penyampaian materi terpaksa menggunakan akses jaringan lokal karena akses internet di sekolah tersebut sedang mengalami kendala. Pada bagian penyampaian cara akses ini, tidak ditemukan kendala yang berarti dan para guru dapat mengikuti materi yang disampaikan dan dapat menerapkan langkah-langkah akses sistem pembelajaran online ini dengan baik.

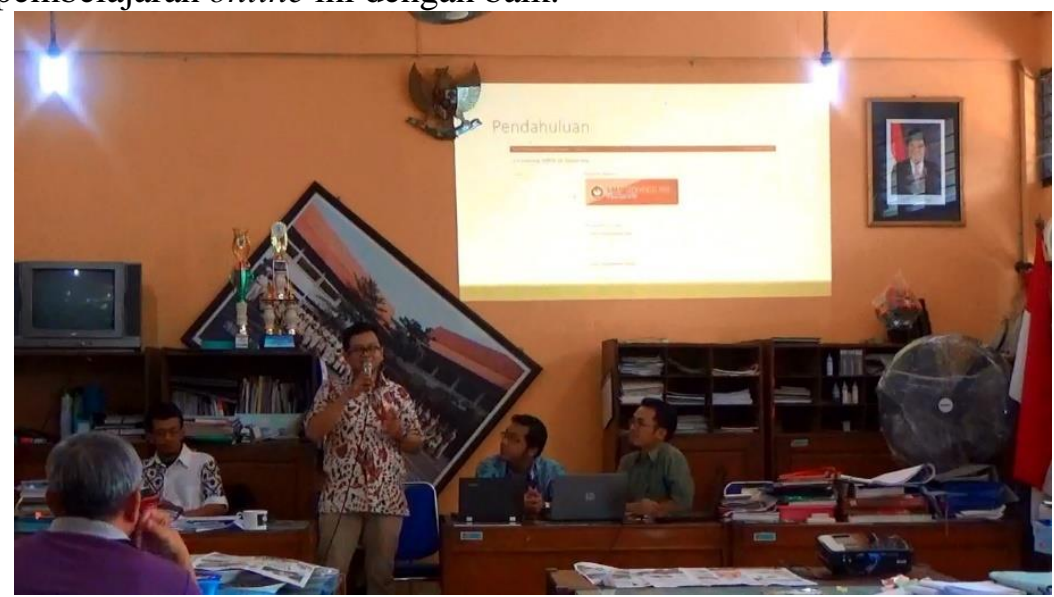

Gambar 3 Pemaparan cara akses sistem media pembelajaran online

Penyampaian materi cara pembuatan soal juga tidak mengalami kendala yang berarti. Namun, terdapat perbedaan kondisi pada bagian materi ini, yaitu pengaturan yang banyak untuk pembuatan soal sehingga waktu yang diperlukan pada bagian ini lebih banyak dibandingkan waktu untuk penyampaian cara akses. Pengaturan-pengaturan yang disampaikan kepada guru hanya diberikan bagian-bagian yang penting untuk diketahui oleh guru, hal ini dilakukan untuk mencegah malfungsi dari soal-soal yang telah dibuat. 


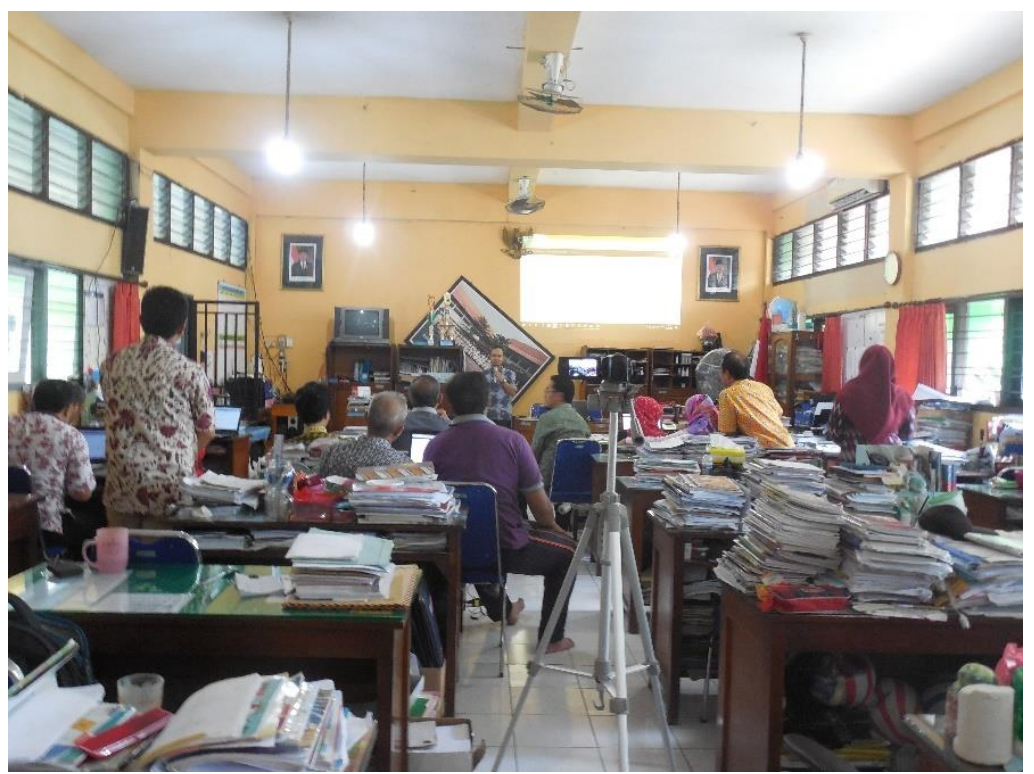

Gambar 4 Pemaparan teknis pembuatan soal berbasis online

Pelatihan in cukup membuat para guru antusias, terbukti hasil pelatihan yang dilakukan oleh guru melalui bentuk modul materi dan kuis di dalam sistem tersebut telah tercapai. Upaya pemateri dalam memberikan panduan secara maksimal dapat diimbangi oleh para guru ketika mengikuti langkah-langkah pengoperasian yang ditunjukkan oleh pemateri utama. Tabel 1 menunjukkan ketercapaian guru dalam melaksanakan panduanpraktik pengoperasian sistem manajemen pembelajaran ini.

Tabel 1 Beberapa Pencapaian Hasil Modul Materi, Tugas, dan Kuis oleh Guru SMPN 30

Semarang (dihitung per langkah pengoperasian)

\begin{tabular}{|c|l|c|c|c|}
\hline No. & \multicolumn{1}{|c|}{ Mata Pelajaran } & Materi & Kuis & Tugas \\
\hline 1 & Pendidikan Agama Islam & $21 / 23$ & $15 / 15$ & $30 / 30$ \\
\hline 2 & Pendidikan Agama Katolik & $16 / 23$ & $15 / 15$ & $30 / 30$ \\
\hline 3 & Pendidikan Agama Kristen & $16 / 23$ & $14 / 15$ & $30 / 30$ \\
\hline 4 & Pendidikan Agama Hindu & $17 / 23$ & $14 / 15$ & $30 / 30$ \\
\hline 5 & Pendidikan Agama Budha & $17 / 23$ & $15 / 15$ & $30 / 30$ \\
\hline 6 & Bahasa Indonesia 1 & $23 / 23$ & $15 / 15$ & $30 / 30$ \\
\hline 7 & Bahasa Indonesia 2 & $23 / 23$ & $14 / 15$ & $30 / 30$ \\
\hline 8 & Pendidikan Kewarganegaraan & $20 / 23$ & $15 / 15$ & $30 / 30$ \\
\hline 9 & Matematika 1 & $23 / 23$ & $14 / 15$ & $27 / 30$ \\
\hline 10 & Matematika 2 & $20 / 23$ & $15 / 15$ & $29 / 30$ \\
\hline 11 & Fisika & $23 / 23$ & $15 / 15$ & $27 / 30$ \\
\hline 12 & Sejarah & $23 / 23$ & $15 / 15$ & $30 / 30$ \\
\hline
\end{tabular}

Pada tabel 1, mata kuliah yang ditampilkan merupakan beberapa matakuliah yang diamati sebagai hasil evaluasi kegiatan pengabdian masyarakat yang dilakukan, terapat beberapa pembagian matakuliah seperti Bahasa Indonesia dan Matematika yang terbagi menjadi dua karena terdapat lebh dari satu guru dalam mata pelajaran yang sama yang melakukan praktik pembuatan modul, tugas, dan tugas dalam sistem manajemen pembelajaran berbasis daring yang dikembangkan, kejadian di lapangan hampir semua guru mata pelajaran mengikuti pelatihan pendampingan ini, namun keterbatasan tempat menbuat pengamatan dan pengambilan dokumentasi menjadi terbatas. Penilaian dilakukan melalui hasil pencapaian guru dalam 
mengikuti tahapan setiap pembuatan modul atau kuis atau tugas dan bukan keseluruhan standar kompetensi yang harus diajarkan oleh guru, hal ini dilakukan karena keterbatasan waktu pendampingan yang tidak memungkinkan seluruh standar kompetensi ditransformasikan ke dalam modul, kuis, dan tugas di dalam sistem manajemen pembelajaran yang dikembangkan untuk SMPN 30 Semarang. Secara umum terjadi peningkatan kemampuan guru dalam mengoperasikan sistem manajemen pembelajaran yang dikembangkan. Hal tersebut dibuktikan dari tiga bentuk perangkat daring yang dibuat yang terdiri dari pembuatan modul, kuis, dan tugas menghasilkan peningkatan pencapaian guru dalam melaksanakan pembuatan perangkat media pembelajaran sesuai lagkah mulai langkah paling awal hingga langkah paling akhir. Pada tahap pembuatan materi para guru masih banyak yang belum mencapai tahap akhir pembuatan modul, hal berbeda terjadi pada tahap pembuatan kuis dan tugas yang mana langkah tertinggal guru dan jarak ketertinggalannya lebih sedikit dibandingkan saat pembuatan modul. Para guru mulai terbiasa dengan menu-menu dan langkah-langkah yang terdapat pada sistem manajemen pembelajaran yang disediakan. Hal lain yang dapat ditemukan selama kegiatan pendampingan adalah pada mata pelajaran eksakta sepertia matematika dan fisika, para guru pengampu mata pelajaran tersebut tidak tuntas mengikuti langkah pembuatan tugas dan kuis. Ketidaktuntasan terseut bukan karena guru-guru pengampu mata pelajaran matematika dan fisika tidak mampu menyelesaikan, namun karena persyaratan untuk menyertakan notasi matematika yang tentu menjadi tantangan dalam pengembangan sistem manajemen pembelajaran berikutnya.

Berdasarkan kegiatan yang telah dilakukan, beberapa masukan diberikan kepada tim pengabdian masyarakat antara lain:

1. Sistem yang dikembangkan menggunakan CMS Moodle ini masih dirasa terlalu berat dari sisi koneksi jaringan internet.

2. Proses pembuatan soal masih diyakini rumit walaupun hasil pengaturan soal tersebut dapat memberikan hasil yang lebih maksimal untuk pembelajaran khususnya pada bagian pendisiplinan siswa dalam pengumpulan tugas.

3. Perlunya pendampingan yang lebih intensif kepada guru-guru tentang penggunaan sistem pembelajaran online ini.

\section{KESIMPULAN}

Sistem yang dikembangkan mampu membuat para guru terbantu dan sangat tertarik dengan sistem yang dikembangkan ini. Pemberian sistem berupa hibah ini menambah ketertarikan guru dan para gruu berinisiatif untuk terus menggunakan sistem ini. Pendampingan terhadap guru secara lebih intensif harus dilakukan supaya guru lebih terbiasa dan penerapannya pada pembelajaran dapat lebih optimal.

\section{SARAN}

Saran-saran untuk untuk penelitian lebih lanjut untuk menutup kekurangan penelitian. Tidak memuat saran-saran diluar untuk penelitian lanjut.

\section{UCAPAN TERIMA KASIH}

Penulis mengucapkan terima kasih kepada Universitas Dian Nuswantoro dan LPPM Universitas Dian Nuswantoro yang telah memberi dukungan financial dan sumber daya fisik dan non-fisik terhadap penelitian ini. 


\section{DAFTAR PUSTAKA}

[1] UU No 14 Tahun 2005 tentang Guru dan Dosen.

[2] https://kominfo.go.id/index.php/content/detail/3834/Siaran+Pers+No.+17-PIHKOMINFO-2-

2014+tentang+Riset+Kominfo+dan+UNICEF+Mengenai+Perilaku+Anak+dan+Rem aja+Dalam+Menggunakan+Internet+/0/siaran_pers, diakses tanggal 10 Februari 2017

[3] http://smp.labschool.upi.edu/2011/10/media-pembelajaran-berbasis-internet-elearning/, diakses tanggal 10 Februari 2017

[4] https://tenjocity.wordpress.com/2012/05/30/media-pembelajaran-berbasis-internet/, diakses tanggal 10 Februari 2017 